\title{
Measuring MSMEs' Accounting Comprehension for Education of Financial Accounting Standard for MSMEs
}

\author{
Yumniati Agustina* \\ Accounting Program \\ Ahmad Dahlan Institute of Technology \& Business Jakarta \\ Jakarta, Indonesia \\ yumniatiagustina@itb-ac.id
}

\author{
Widyat Nurcahyo \\ Informatics Program \\ Tama Jagakarsa University \\ Jakarta, Indonesia \\ widyatnurcahyo@jagakarsa.ac.id
}

\author{
E Ermalina \\ Accounting Program \\ Ahmad Dahlan Institute of Technology \& Business Jakarta \\ Jakarta, Indonesia \\ ermalina@itb-ac.id
}

\author{
Sri Setianingsih \\ Accounting Program \\ Ahmad Dahlan Institute of Technology \& Business Jakarta \\ Jakarta, Indonesia \\ srisetianingsih@itb-ac.id
}

\begin{abstract}
One of the few obstacles that often encountered in MSMEs is the lack of attention to financial accounting. This is due to the lack of accounting knowledge. Therefore, accounting education is important so that MSMEs can prepare financial reports in conformance with Financial Accounting Standards for Micro, Small, and Medium Entities (SAKEMKM). This preliminary study measures the level of accounting comprehension, looks for the factors that influence it, and provides recommendations for designing accounting education for MSMEs. These recommendations are the novelty of this research. The analysis was carried out using three approaches. The descriptive analysis used graphs and proportion values. The comparative analysis used MannWhitney and Kruskal-Wallis difference tests. And multiple regressions were carried out to perform associative analysis. The results of the analysis show that MSMEs have a very low comprehension of accrual-based cash and fixed asset depreciation. Also, it was found that MSMEs that have been in business for more than 5 years have a better comprehension of accounting than those for less than 5 years. Recommendations given include: (1) Prioritizing MSMEs with a business duration of more than 5 years in the early stages of education; (2) Focus on accounting aspects with low comprehensions, such as accrual basis assumptions, adjustments, depreciation, financial statement components, accrued expenses, and unearned income; and (3) Repeating the materials with good comprehension, accompanied by sufficient examples.
\end{abstract} EMKM

Keywords- MSMEs, accounting comprehension, SAK-

\section{INTRODUCTION}

The contribution of MSMEs to the Indonesian economy includes increasing GDP, creating jobs and contributing to non-oil and gas exports [1], [2]. The years 1998 and 2012 proved that MSMEs could survive the economic crisis, as indicated by the positive growth achieved by MSMEs during the time of crisis [2]. Some of the main obstacles faced by MSMEs in developing their businesses are difficulties in preparing financial reports [3], [4] and management of funds using proper accounting [5], [6]. MSME constraints in preparing financial reports are comprehension and knowledge of accounting in their preparation, time and cost limitations [7]. One of the factors that hinders MSMEs in implementing accounting, among others, is their educational background, has never attended accounting training and deems accounting is unnecessary [6]. Other obstacles are: (1) It is difficult to set aside time to make accounting records because MSME owners often have concurrent duties in running their business; (2) Lack of knowledge or skills of MSMEs' owners related to accounting records; (3) MSMEs' owners think that the business they are running is not that big, so accounting records are not required; (4) Pay less attention to accounting management because the impact is not clearly visible or does not directly affect the continuity of its business; (5) Absence of accounting skilled worker, especially in bookkeeping and financial reports; and (6) Perceive that financial statements are complicated [8].

Accounting records must be in accordance with every transaction that occurs and based on applicable accounting standards. Accounting standards have accounting treatment starting from recognition, measurement, presentation and disclosure, which serve as guidelines in preparing reliable financial reports. In general, MSMEs do not use existing standards in preparing financial reports. MSME financial reports often use a cash basis taken from sources of cash transfers. Financial reports on a cash basis certainly do not reflect the actual financial condition of the company. The company records transactions when cash receipts \& disbursements occur without taking into account any debt or receivables. The cash base assumption also records income and expense transactions when cash receipts or payments have been made.

In 2009, the Financial Accounting Standards Board of the Indonesian Institute of Accountants (DSAK IAI) issued SAK Entitas Without Public Accountability (SAK ETAP) which was intended to be used by small \& medium entities. However, along with its development, there is a need regarding the availability of simpler accounting standards due to limited human resources. Therefore, in order to help 
MSMEs meet their financial reporting needs, the DSAK IAI in 2016 prepared the Financial Accounting Standards for Micro, Small \& Medium Entities (SAK EMKM) which became effective as of January 2018. This standard is a reference and guideline in preparing financial reports, is a form of quality improvement, transparency and credibility in the preparation of financial reports for micro, small \& medium enterprises. SAK EMKM contains accounting treatment which includes the recognition, measurement, presentation and disclosure of each element in the financial statements. In order for the resulting financial information to be more useful, the financial information must be able to enhance qualitative characteristics, namely that the information is comparable, verifiable, timely and understandable [9].

Financial information comprehension includes classification, characterization and presentation of information. This is inseparable from a good accounting information system that starts from the accounting equation and the accounting cycle [10]. The accounting equation is the equation between debit $\&$ credit which provides the basis for a system for recording multiple bookkeeping transactions which is often called double-entry accounting [11]. In a double-entry system, for each debit there must be a credit and this equation shows the rules and effects of debit / credit on each type of account. The accounting cycle is the steps of recording transactions and preparing financial reports. These two things are the basic terminology used in collecting accounting data. Therefore, a reliable level of accounting understanding is needed in preparing financial reports, starting from the recording of double bookkeeping transactions and the accounting cycle.

Accounting comprehension includes a person's ability to understand and carry out the accounting process, starting from transaction source documents, accounting cycles (accounting processes), to financial reports based on accounting standards. Accounting comprehension can be used as a reference in presenting quality financial information. One of the factors that influence the success of MSMEs is the comprehension of accounting. This has implications so that in the future MSMEs will improve their accounting comprehension to sustain the success of MSMEs [12]. Another study explains that attitudes and experiences have a partially significant relationship to comprehend accounting information. The results also explain that comprehension of accounting information as an intermediary variable has a dominant relationship to business success [13].

Implementing SAK EMKM is not an easy thing in practice. Many factors were thought to be obstacles in implementing SAK EMKM. Among them are: (1) SAKEMKM socialization [14], [15]; (2) the owner's education level [14], [15]; (3) the perception of MSMEs owners [14]; (4) the comprehension of accounting [14]; (5) does not separate personal and business money [15]; (6) lack of human resources with sufficient financial accounting standards knowledge [15]; (7) age of the owner or manager of the MSME [15]; and (8) the number of MSME transaction activities [15]. The various variables that influence the implementation of SAK-EMKM, accounting comprehension was the most dominant variable [14]. Several studies have discussed the accounting comprehension of MSMEs, among others, the results are mentioned below. Information and socialization, educational background, education level, age, and business scale do not have a significant effect on SAKEMKM comprehension [16].

Accounting comprehension and business size have a positive and significant effect on the quality of financial reports on MSMEs in Buleleng District [17]. The level of MSMEs' comprehension toward SAK-EMKM in Pekanbaru was quite high. A sufficient level of comprehension, especially comprehension about the concept of accrual basis assumptions, the concept of business entities, and the concept of financial statement presentation. For the concept of historical cost measurement, business continuity assumptions, and financial statement components, MSMEs have a high comprehension [18]. The prospect of implementing SAKEMKM on the quality of financial reporting was very minimal because MSMEs' comprehension of bookkeeping in accordance with SAK-EMKM was still very low [16]

The same thing was also found from the results of the survey in the financial report preparation training based on SAK-EMKM which was held by ITB-AD lecturers with SMEs under Pinbas-MUI on April 30, 2019. It was found that the majority did not know about SAK-EMKM [19]. Thus, to increase accounting comprehension enough to implementing SAK-EMKM in MSMEs, an education program must be built first.

This research is a preliminary study in designing an accounting education program appropriate for SAK EMKM implementation, measuring the level of accounting comprehension of MSMEs. From the results of these measurements, it can be seen what indicators of accounting are already comprehended, poorly comprehended, and even not yet comprehended by MSMEs. This research also examines what factors affect the accounting comprehension based on the profile of MSME business actors, namely: gender, age, education level, status in business and length of business. And in the end, the results of this study can provide recommendations on designing the education program in the context of implementing SAK EMKM. This is the novelties compared to other studies.

\section{METHODS}

This research is a quantitative research with descriptive, comparative, and associative approach and conducted using the following steps. Data collection, including: research instruments design, validity and reliability tests, questionnaires distribution. The instrument in this study was a questionnaire with a total of 20 questions, built based on accounting treatment according to SAK EMKM, which consists of 4 main indicators, namely: [20] Indicator 1: Recognition \& measurement of assets, liabilities, equity, income and expenses are the main elements of financial statements. Consists of 5 questions. Indicator 2: Basic Assumptions. It is an assumption used as the basis for the financial statement preparation process. This indicator contains all elements of financial statements that meet the recognition criteria. Consists of 3 questions. Indicator 3 : Presentation of Financial Statements which explains that the financial statements must be presented with fair presentation principles which require fair presentation of the effects of transactions, other events and conditions in accordance with the definition \& recognition criteria of assets, liabilities, income and expenses. The objective of fair presentation is to 
achieve relevant financial statements, accurate representation, comparability and understanding. Consists of 4 questions. Indicator 4: Adjustment of Cash to Accrual. An entity that prepares financial statements using a cash basis assumption must convert these financial statements into an accrual assumption by making adjustments at the end of the period. Adjustments are made consistently as long as there are no changes in the basic assumptions. Consists of 8 questions. The questionnaire's validity measurement was carried out by conducting a bivariate correlation between each indicator score and the total construct score. The measurement of reliability was carried out using the Cronbach alpha $(\alpha)$ statistical test. The questionnaire were distributed online through the WhatsApp groups of PINBAS MUI, HIPMIKIMDO, LPP HIPMIKIMDO, Batik Sakera, and the SME Community.

Data analysis, including: analysis of data by item and indicator, analysis of data based on profiles of MSME respondents, analysis of the influence of profiles of MSME respondents. Data analysis on each item was carried out by calculating the frequency of respondents' answers to each questionfrom the item. Data analysis per indicator was carried out by adding up the frequency of respondents' answers per question item included in each indicator. Then it was converted into percentage and the average of all respondents was calculated. Comparative analysis of data based on profiles of MSME respondents used non-parametric statistical tests, namely the Mann-Whitney test and the Kruskal-Wallis test. The associative analysis of the influence of profiles used firstorder multiple linear regression. The variables used in this study are shown in Table I. The summary of analysis tools and hypothesis are shown in Table II. Conclusions, including: SAK-EMKM implementation recommendations, research conclusions and suggestions.

TABLE I. OPERATIONALIZATION OF VARIABLES

\begin{tabular}{|c|c|c|c|}
\hline Variable & Category & Measurement & Code \\
\hline $\mathrm{Y}$ & $\begin{array}{l}\text { Accounting } \\
\text { Comprehension = Answer } \\
\text { Accuracy }\end{array}$ & Ratio & \\
\hline $\mathrm{X} 1$ & Gender & Nominal & $\begin{array}{l}0=\text { Female } \\
1=\text { Male }\end{array}$ \\
\hline $\mathrm{X} 2$ & Age Group & Nominal & $\begin{array}{l}0=<20 \\
1=20-25 \\
2=26-31 \\
3=32-37 \\
4=38-43 \\
5=44-49 \\
6=>=50\end{array}$ \\
\hline $\mathrm{X} 3$ & Education Level & Ordinal & $\begin{array}{l}0=\mathrm{SMA} \\
1=\mathrm{D} 3 \\
2=\mathrm{S} 1 \\
3=\mathrm{S} 2 \\
4=\mathrm{S} 3\end{array}$ \\
\hline $\mathrm{X} 4$ & Status in Business & Nominal & $\begin{array}{l}0=\text { Owner } \\
1 \\
\text { Employee }\end{array}$ \\
\hline $\mathrm{X} 5$ & Business Length & Nominal & $\begin{array}{l}0=<5 \\
\text { years } \\
1=>=5 \\
\text { years }\end{array}$ \\
\hline
\end{tabular}

TABLE II. ANALYSIS TOOLS AND HYPOTHESIS TESTING

\begin{tabular}{|c|c|c|c|}
\hline $\begin{array}{l}\text { Variables being } \\
\text { tested }\end{array}$ & Statistical analysis/test tools & Research hypothesis & $\begin{array}{l}\text { Statistical } \\
\text { hypothesis }\end{array}$ \\
\hline $\mathrm{X} 1, \mathrm{Y}$ & $\begin{array}{l}\text { Comparative analysis of gender } \\
\text { profiles using the Mann Whitney U- } \\
\text { Test }\end{array}$ & $\begin{array}{l}\text { Comparative hypothesis: there are differences in the mean value of } \\
\text { accounting understanding between genders }\end{array}$ & $\begin{array}{l}\text { Ho1: } \mu 1=\mu 2 \\
\text { Ha1: } \mu 1 \neq \mu 2\end{array}$ \\
\hline $\mathrm{X} 2, \mathrm{Y}$ & $\begin{array}{l}\text { Comparative analysis of age group } \\
\text { profiles with the Kruskal-Wallis } \\
\text { One Way Test }\end{array}$ & $\begin{array}{l}\text { Comparative hypothesis: there are differences in the mean value of } \\
\text { accounting comprehension between age groups samples }\end{array}$ & $\begin{array}{l}\text { Ho } 2: \mu 0=\mu 1=\mu 2= \\
\mu 3=\mu 4=\mu 5=\mu 6 \\
\text { Ha2: } \mu 0 \neq \mu 1 \neq \mu 2 \neq \\
\mu 3 \neq \mu 4 \neq \mu 5 \neq \mu 6\end{array}$ \\
\hline $\mathrm{X} 4, \mathrm{Y}$ & $\begin{array}{l}\text { Comparative analysis of status in } \\
\text { business with the Mann Whitney U- } \\
\text { Test }\end{array}$ & $\begin{array}{l}\text { Comparative hypothesis: there is a difference in the mean value of } \\
\text { accounting comprehension between samples of owners and } \\
\text { samples of employees (status in business) }\end{array}$ & $\begin{array}{l}\text { Ho4: } \mu 1=\mu 2 \\
\text { Ha4: } \mu 1 \neq \mu 2\end{array}$ \\
\hline $\mathrm{X} 5, \mathrm{Y}$ & $\begin{array}{l}\text { Comparative analysis of length of } \\
\text { business with the Mann Whitney U- } \\
\text { Test }\end{array}$ & $\begin{array}{l}\text { Comparative hypothesis: there is a significant difference in the } \\
\text { mean value of accounting comprehension between the samples of } \\
\text { business length }<5 \text { years and }>5 \text { years. }\end{array}$ & $\begin{array}{l}\text { Ho5: } \mu 1=\mu 2 \\
\text { На5: } \mu 1 \neq \mu 2\end{array}$ \\
\hline $\mathrm{X} 1, \mathrm{Y}$ & $\begin{array}{l}\text { Associative Analysis: } \\
\text { t-test }\end{array}$ & $\begin{array}{l}\text { Associative Hypothesis: there is a significant effect of the gender } \\
\text { profiles on accounting comprehension. }\end{array}$ & $\begin{array}{l}\text { Ho: } ß 1=0 \\
\text { Ha: } ß 1 \neq 0\end{array}$ \\
\hline $\mathrm{X} 2, \mathrm{Y}$ & $\begin{array}{l}\text { Associative Analysis: } \\
\text { t-test }\end{array}$ & $\begin{array}{l}\text { Associative Hypothesis: there is a significant effect of the age group } \\
\text { profiles on accounting comprehension. }\end{array}$ & $\begin{array}{l}\text { Ho: } \beta 2=0 \\
\text { Ho: } \beta 2 \neq 0\end{array}$ \\
\hline $\mathrm{X} 3, \mathrm{Y}$ & $\begin{array}{l}\text { Associative Analysis: } \\
\text { t-test }\end{array}$ & $\begin{array}{l}\text { Associative Hypothesis: there is a significant effect of the education } \\
\text { level profiles on accounting comprehension. }\end{array}$ & $\begin{array}{l}\text { Ho: }: 33=0 \\
\text { Ho: } \beta 3 \neq 0\end{array}$ \\
\hline $\mathrm{X} 4, \mathrm{Y}$ & $\begin{array}{l}\text { Associative Analysis: } \\
\text { t-test }\end{array}$ & $\begin{array}{l}\text { Associative Hypothesis: there is a significant effect of the status in } \\
\text { business profiles on accounting comprehension. }\end{array}$ & $\begin{array}{l}\text { Ho: } ß 4=0 \\
\text { Ho: } ß 4 \neq 0\end{array}$ \\
\hline $\mathrm{X} 5, \mathrm{Y}$ & $\begin{array}{l}\text { Associative Analysis: } \\
\text { t-test }\end{array}$ & $\begin{array}{l}\text { Associative Hypothesis: there is a significant effect of the length of } \\
\text { business profiles on accounting comprehension. }\end{array}$ & $\begin{array}{l}\text { Ho: }: 35=0 \\
\text { Ho: } ß 5 \neq 0\end{array}$ \\
\hline $\begin{array}{l}\mathrm{X} 1 ; \mathrm{X} 2 ; \mathrm{X} 3 ; \mathrm{X} 4 ; \mathrm{X} 5 \\
\mathrm{Y}\end{array}$ & $\begin{array}{l}\text { Associative Analysis: } \\
\text { F-test }\end{array}$ & $\begin{array}{l}\text { Associative Hypothesis: simultaneously, there is a significant effect } \\
\text { of the overall of MSMEs profiles on accounting comprehension. }\end{array}$ & $\begin{array}{l}\text { Ho: } \beta 1=\beta 2=\beta 3= \\
\beta 4=\beta 5=0 \\
\text { Ha: } \beta 1 \neq \beta 2 \neq \beta 3 \neq \\
\beta 4 \neq \beta 5 \neq 0\end{array}$ \\
\hline
\end{tabular}




\section{RESULT AND DISCUSSION}

\section{A. The results of the validity analysis of the research instrument}

The results calculation of the correlation bivariate from SPSS for each score of four indicators (recognition and measurement; basic assumptions; presentation of financial statements; and adjustment of cash to accrual) for each of the total construct scores showed significant results. So, it can be concluded that each question indicator is valid.

\section{B. The results of the reliability Analysis of Research Instruments}

The SPSS output shows that each value "Cronbach's Alpha based on standardized" $>0.70$. So that all research instruments in all indicators are said to be reliable.

\section{Accuracy of answers for each question item}

Based on multiple pie charts of the answer accuracy, if further analyzed, the high answer accuracy (above 50\%) is found in the $3 \mathrm{rd}$, 4th, 7th, 8th, 10th, 16th, and 17th question. These seven questions were in the form of positive questions, and contain questions that were easy to understand with simple logic.

Wrong answers with a high percentage were found in the 2nd, 5th, 6th, 9th, 11th, 15th, and 18th question. These seven questions have the same form of negative questions.

Answers to "Do not know" with a high percentage were found on the 1st, 12th, 13th, 14th, 19th, and 20th question. These six questions have something in common, namely that they contain questions that require sufficient accounting knowledge.

From this analysis, when viewed from the accuracy of answers based on individual questions, it can be concluded that the respondents' comprehension of accounting is still low. Most respondents only answered with personal assumptions, only with logic, without sufficient accounting knowledge. This is consistent with research [21] and [22] which states that one of the challenges faced by MSME owners in Indonesia is a lack of accounting knowledge. Research [16] states that MSMEs had very low comprehension of bookkeeping in accordance with SAK-EMKM. It is also in line with research [23] which states that one of the difficulties of MSMEs is the unavailability of complete accounting information and the lack of accounting practices. In fact, this plays a very important role in accounting implementation [24].

\section{Average answer accuracy for each indicator}

When analyzed based on indicators, on indicator 2 , the level of accuracy is quite high (60\%). This indicator is a basic assumption, with questions that are easy to understand with logic only. Medium accuracies $(30 \%-50 \%)$ were found in indicators 1 and 3. Both of these indicators required basic accounting knowledge to answer them. These results are similar to research [18] which states that the comprehension of basic assumptions and measurements is at a sufficient level.

Meanwhile, in the indicator 4, the highest answer is "do not know" $(48 \%)$. This indicator required a higher level of basic accounting knowledge, as well as the introduction of the term "accruals" which respondents might not have heard before. Research [25] concluded similar results that MSMEs were having difficulties in accrual-based accounting.

\section{E. Average answer accuracy based on MSME respondent profiles \\ 1. Gender Profile}

Based on the average percentage line graph, it can be analyzed that the response patterns of respondents, both male and female, still follow the average answer pattern. So it can be assumed that there is no real difference in accounting comprehension between men and women. Based on the two independent sample difference test with Mann-Whitney Utest, the results from SPSS showed the value of Sig $=0.607$. Because Sig> 0.05, then Ho is accepted, meaning that there was no significant difference in accounting comprehension between men and women. This result is different from research [24] and [26] which state that gender affects accounting comprehension. The differences may occur due to differences in the research population.

\section{Age Group Profile}

Based on the percentage line graph, it can be analyzed that the response patterns of respondents from all age groups and based on indicators still follow the overall answer pattern. However, if we look at each item of the question, there were some differences, especially in the age group with a small number of respondents. This difference was presumably because the number of respondents for this group was too small, so it cannot represent the population. It could be presumed that there was no significant difference in accounting comprehension between age groups.

Based on the Kruskal-Wallis test from the results of SPSS processing, the $\mathrm{Sig}=0.353$ was obtained. Because Sig $>0.05$, then Ho is accepted, meaning that there is no significant difference in accounting comprehension between age groups. This result is in line with research [25] and [16] which states that the age of the owner of MSMEs has no influence.

\section{Education Level Profile}

Based on the percentage line graph, it can be analyzed that the response patterns of respondents from all education levels and based on indicators still follow the overall answer pattern. However, if we look at each item of the question, there were some differences, especially in the education level groups with a small number of respondents. This difference was presumably because the number of respondents for this group was too small, so it cannot represent the population. It could be presumed that there was no significant difference in accounting comprehension between education level groups.

Based on the Kruskal-Wallis test from the results of SPSS processing, the $\mathrm{Sig}=0.249$ was obtained. Because Sig $>0.05$, then Ho is accepted, meaning that there is no significant difference in accounting comprehension between education level groups. This is in line with research [16] which states that education level has no effect on the understanding of MSME accounting standards. Similar results in the study [27] stated that educational background has no positive effect on the level of accounting comprehension. On the other hand, the educational background of MSME owners is one of the obstacles to implementing SAK-EMKM [15]. 


\section{Status in Business Profile}

Based on the average percentage line graph, it can be analyzed that the response patterns of respondents, both owners and employees, still follow the overall answer pattern. So it could be assumed that there was no real difference in accounting comprehension between owners and employees. Based on the two independent sample difference test with Mann-Whitney U-test, the results from SPSS showed the value of Sig $=0.941$. Because Sig $>0.05$, then Ho is accepted, meaning that there was no significant difference in accounting comprehension between owners and employees.

\section{Length of Business Profile}

Based on the average percentage line graph, it can be analyzed that the response patterns of respondents, with more than 5 years or less than 5 years in business, have different patterns. So it could be assumed that there was a difference in accounting comprehension between MSME with more than 5 years in business and the ones with less than 5 years.. Based on the two independent sample difference test with MannWhitney U-test, the results from SPSS showed the value of $\mathrm{Sig}=0.032$. Because $\mathrm{Sig}<0.05$, then Ha is accepted, meaning that there was a significant difference in accounting comprehension between MSME with more than 5 years in business and the ones with less than 5 years. The results of this study are consistent with research [28] which states that length of business has a significant positive effect on accounting understanding for MSMEs.

\section{F. The effect of MSME Profiles on accounting comprehension \\ 1. Multiple Linear Regression Equation}

The regression equation model used was:

$$
\begin{aligned}
& \text { with: } \\
& \mathrm{Y}=\text { Answer Accuracy Level } \\
& \mathrm{X} 1=\text { Gender } \\
& \mathrm{X} 2 \text { = Age Group } \\
& \mathrm{X} 3=\text { Education Level } \\
& \mathrm{X} 4=\text { Status in Business } \\
& \mathrm{X} 5=\text { Length of Business }
\end{aligned}
$$$$
\mathrm{Y}=\beta 0+\beta 1 \mathrm{X} 1+\beta 2 \mathrm{X} 2+\beta 3 \mathrm{X} 3+\beta 4 \mathrm{X} 4+\beta 5 \mathrm{X} 5+\mathrm{e}
$$

Regression using SPSS produced the following regression coefficients:

$$
\mathrm{Y}=0.414+0.011 \mathrm{X} 1-0.022 \mathrm{X} 2+0.007 \mathrm{X} 3+0.043 \mathrm{X} 4+
$$

$$
0.060 \times 5+\mathrm{e}
$$

The regression equation above could be expressed by :

- A constant of 0.414 states that if the independent variable is considered constant, then the average answer accuracy is 0.414 points.

- The gender regression coefficient of 0.011 states that male gender will further increase $\mathrm{Y}$ (answer accuracy) by 0.011 although the effect is not significant compared to women.
- $\quad$ The age group regression coefficient (-0.022) states that the higher the age group, the lower the answer accuracy rate is 0.022 and has a significant effect.

- The regression coefficient for education level is 0.007 , which states that the higher the level of education, the greater the $\mathrm{Y}$ (accuracy of answer) will increase by 0.007 even though the effect is not significant.

- The regression coefficient of status in business is 0.043 , which states that employee status will further increase Y (answer accuracy) by 0.043 compared to the owner, even though the effect is not significant.

- The regression coefficient for the length of the business is 0.060 , which states that the longer the business life ( $>5$ years) will increase the accuracy of the answer by 0.060 compared to the business age $<5$ years and has a significant effect.

\section{Individual parameter significance test ( $t$-test)}

The t-test using SPSS for each variable gave the following results:

- $\quad$ The Sig value of the gender variable is $0.709>0.05$, then Ho is accepted. The t-count value is $0.374<\mathrm{t}-$ table 1.980, then Ho is accepted. This means that the effect of gender on the accuracy of the answers is not significant.

- $\quad$ The Sig value of the age group variable is 0.029 $<0.05$, then Ho is rejected. The t-count value is 2.216>t-table 1.980, then Ho is rejected. This means that the effect of age on the accuracy of the answers is significant.

- The Sig value of the education level variable is $0.555>0.05$, then Ho is accepted. The t-count value is $0.592<\mathrm{t}$-table 1.980, then Ho is accepted. This means that the effect of education level on the accuracy of the answers is not significant.

- The Sig value of the status in business variable is $0.404>0.05$, then Ho is accepted. The t-count value is $0.838<\mathrm{t}$-table 1.980, then Ho is accepted. This means that the effect of status in business on the accuracy of the answers is not significant.

- The Sig value of the length of business variable is $0.031<0.05$, then Ho is rejected. The $\mathrm{t}$-count value is $2.186>t$-table 1.980, then Ho is rejected. This means that the effect of length of business on the accuracy of the answers is significant.

\section{Simultaneous significance test ( $F$-test)}

From the ANOVA table or the F-Test of the SPSS results, the Sig value is 0.052>0.05, then Ho is accepted. The F-count value is $2.281<$ F-table 2.31, then Ho is accepted. This means that simultaneously, all independent variables have no significant effect on the accuracy of the answer.

\section{Coefficient of Determination}

The result of SPSS data processing showed that the amount of Adjusted R2 was 0.101 . This means that $10.1 \%$ of answer accuracy was influenced by the MSMEs profiles 
(length of business, education level, age group, gender, and status in business).

\section{Comparative Analysis}

Comparison of the analysis of respondents' answers regarding accounting comprehension with the various methods above, summarized in table III, as follows:

TABLE III. COMPARISON OF ANALYSIS RESULTS

\begin{tabular}{|c|c|c|c|c|}
\hline $\begin{array}{c}\text { MSMEs } \\
\text { Profile }\end{array}$ & Percentage and Graphs & Mann-Whitney Test & Kruskal-Wallis Test & Multiple Regression \\
\hline Gender & $\begin{array}{l}\text { There was no difference in } \\
\text { accounting comprehension } \\
\text { between men and women. }\end{array}$ & $\begin{array}{l}\text { Ho accepted, There was no } \\
\text { significant difference in } \\
\text { accounting comprehension } \\
\text { between men and women. }\end{array}$ & - & $\begin{array}{l}\text { Ho accepted, the effect of } \\
\text { gender on the accuracy of } \\
\text { the answers was not } \\
\text { significant. }\end{array}$ \\
\hline Age Group & $\begin{array}{l}\text { There was no difference in } \\
\text { accounting comprehension } \\
\text { between age groups. }\end{array}$ & - & $\begin{array}{l}\text { Ho accepted, There was no } \\
\text { significant difference in } \\
\text { accounting comprehension } \\
\text { between age groups. }\end{array}$ & $\begin{array}{l}\text { Ho rejected, the effect of } \\
\text { age on the accuracy of the } \\
\text { answers was significant. }\end{array}$ \\
\hline $\begin{array}{l}\text { Education } \\
\text { Level }\end{array}$ & $\begin{array}{l}\text { There was no difference in } \\
\text { accounting comprehension } \\
\text { between education levels. }\end{array}$ & - & $\begin{array}{l}\text { Ho accepted, There was no } \\
\text { significant difference in } \\
\text { accounting comprehension } \\
\text { between education levels. }\end{array}$ & $\begin{array}{l}\text { Ho accepted, the effect of } \\
\text { education level on the } \\
\text { accuracy of the answers } \\
\text { was not significant. }\end{array}$ \\
\hline $\begin{array}{l}\text { Status in } \\
\text { Business }\end{array}$ & $\begin{array}{l}\text { There was no difference in } \\
\text { accounting comprehension } \\
\text { between owners and } \\
\text { employees. }\end{array}$ & $\begin{array}{l}\text { Ho accepted, There was no } \\
\text { significant difference in } \\
\text { accounting comprehension } \\
\text { between owners and } \\
\text { employees. }\end{array}$ & & $\begin{array}{l}\text { Ho accepted, the effect of } \\
\text { the status in business on the } \\
\text { accuracy of the answers } \\
\text { was not significant. }\end{array}$ \\
\hline $\begin{array}{l}\text { Length of } \\
\text { Business }\end{array}$ & $\begin{array}{l}\text { There was a difference in } \\
\text { accounting comprehension } \\
\text { between MSME with more } \\
\text { than } 5 \text { years in business } \\
\text { and the ones with less than } \\
5 \text { years }\end{array}$ & $\begin{array}{l}\text { Ho rejected, there was a } \\
\text { significant difference in } \\
\text { accounting comprehension } \\
\text { between MSME with more } \\
\text { than } 5 \text { years in business and } \\
\text { the ones with less than } 5 \\
\text { years. }\end{array}$ & & $\begin{array}{l}\text { Ho rejected, the effect of } \\
\text { length of business on the } \\
\text { accuracy of the answers is } \\
\text { significant }\end{array}$ \\
\hline
\end{tabular}

Most of the results of the analysis are consistent with previous studies, as discussed above. Therefore, these results proper to be used as a recommendation in designing accounting education for MSMEs in the context of implementing SAK-EMKM. Based on the findings described above, the authors propose several recommendations for the SAK-EMKM implementation program for MSMEs, as follows:

a. Based on the analysis of accounting comprehension per item of the questions, it can be recommended that in implementing SAK-EMKM it is better to emphasize mastery of several accounting materials including:

- Historical cost.

- The contents of the notes on the financial statements.

- Accrual basis assumption.

- $\quad$ Posts that need to be adjusted.

- Inventory accounting system.

- Types of depreciation methods and their calculations.

- Recognition of assets, expenses, debts, capital, income.

- Types of financial statements and their components.

- Accounting treatment for Accrued Expenses \& Unearned Revenues.

Meanwhile, for other materials with a fairly good understanding, such as the definition of debt, the definition of income, the concept of business entity, the concept of business continuity, components of financial position report, the concept of accrued income, the concept of prepaid expenses, it is advisable to carry out an adequate review, without the need for in-depth discussion to cut implementation time.

b. Based on the analysis of accounting comprehension by indicator, it was found that the comprehension related to Adjustment of Cash to Accruals was still very weak, so it is recommended to focus on this knowledge, accompanied by real examples. While knowledge related to basic assumptions, recognition and measurement, and presentation of financial statements is sufficient, however, it should be developed further by providing broader insight.

c. Based on the analysis of the MSME profiles, there is only one profile that has a significant effect on accounting comprehension, namely the length of business. Therefore, it is recommended that in the early stages of SAK-EMKM implementation, select MSMEs that have been running their business for more than 5 years. Thus, it is expected to provide strong momentum in the successful implementation.

\section{CONCLUSION}

MSMEs within the scope of the study have a weak comprehension of accounting. This can be concluded from the low average accuracy of the answers. Based on indicators in the questionnaire shows that MSMEs have a very weak understanding of the material of adjusting cash to accruals. From the individual questions, MSMEs have low comprehension about the accounting for depreciation of fixed 
assets. So it is necessary to provide a more focused education with real examples.

Based on the analysis of the MSME profile, the results show that MSMEs who have been running their business for more than 5 years have a higher comprehension of accounting so that they can be selected as the initial target of SAKEMKM education. Finally, this could be done to gain good initial momentum in implementing SAK-EMKM. The profile of gender, age group, education level, and status in the business has no effect on accounting comprehension so that it can be ignored in implementation recommendations.

\section{ACKNOWLEDGMENT}

This research was partly supported by Ahmad Dahlan Institute of Technology \& Business Jakarta.

\section{REFERENCES}

[1] ICMI, "Penguatan UKM dan Koperasi sebagai Pondasi Utama Hadapi Resesi Global," 2019. [Online]. Available: https://www.icmi.or.id/media/siaran-pers/penguatan-ukm-dankoperasi-sebagai-pondasi-utama-hadapi-resesi-global. [Accessed: 14-Nov-2019].

[2] Redaksi WE Online, "UMKM Punya Peran Penting bagi Perekonomian Indonesia," 2019. [Online]. Available: https://republika.co.id/berita/pvrzay17000/umkm-punya-peranpenting-bagi-perekonomian-indonesia. [Accessed: 13-Nov-2019]

[3] F. Fauziyah, "Tantangan UMKM dalam Menghadapi Revolus Industri 4.0 Ditinjau dari Aspek Marketing dan Accounting," JMK (Jurnal Manaj. dan Kewirausahaan), vol. 5, no. 2, pp. 155-172, 2020.

[4] Tatik, "Implementasi SAK EMKM (Standar Akuntansi Keuangan)," J. Relasi, vol. XIV, no. 2, 2018.

[5] E. B. Sanggrama, R. S. Rachmat, and S. Tin, "Sebuah Solusi untuk Perkembangan," J. Akunt. Fak. Ekon. Univ. Maranatha, vol. 12, no. 1 , pp. 146-158, 2020

[6] Y. Setyawati and S. Hermawan, "Persepsi Pemilik Dan Pengetahuan Akuntansi Pelaku Usaha Mikro Kecil Dan Menengah (UMKM)," Ris. Akunt. dan Keuang. Indones., vol. 3, no. 2, pp. $161-168,2018$

[7] A. O. Siagian and N. Indra, "Pengetahuan Akuntansi Pelaku Usaha Mikro Kecil Dan Menengah," Syntax Lit. J. Ilm. Indones., vol. 4 no. 12 , pp. $17-35$, Dec. 2019.

[8] R. V Savitri and S. Safudin, "Pencatatan Akuntansi Pada Usaha Mikro, Kecil Dan Menengah (Studi Pada UMKM Mr Pelangi Semarang)," J. Manaj. Bisnis Dan Inov., vol. 5, no. 2, pp. 117 125,2018

[9] Ikatan Akuntansi Indonesia, Standar Akuntansi Keuangan. Jakarta: Ikatan Akuntansi Indonesia, 2018.

[10] Y. Agustina, "Siklus Akuntansi, Transparansi, Dan Akuntabiltas Atas Pertanggungjawaban Keuangan Dana BOS Di SDIT Depok, Jawa barat," Liquidity, vol. 1, no. 1, pp. 55-66, 2016.

[11] D. E. Kieso, J. J. Weygandt, and D. T. Warfield, Akuntansi Keuangan Menengah. IFRS, 1st ed. Jakarta: Salemba Empat, 2018.

[12] E. Merdekawati and N. Rosyanti, "Faktor-Faktor Yang Mempengaruhi Keberhasilan UMKM (Studi Kasus Pada UMKM Di Kota Bogor)," JIAFE (Jurnal Ilm. Akunt. Fak. Ekon., vol. 5, no.
2, pp. $165-174,2019$

[13] A. D. Rini, "Relevansi Sikap Dan Pengalaman Pelaku Usaha Mikro Kecil Menengah," in Prosiding Seminar Nasional Multi Disiplin Ilmu Kajian Multi Disiplin Ilmu dalam Pengembangan IPTEKS untuk Mewujudkan Pembangunan Nasional Semesta Berencana, 2016, pp. 593-600.

[14] I. Kusuma and V. Lutfiany, "Persepsi UMKM Dalam Memahami SAK EMKM," J. AKUNIDA ISSN, vol. 4, no. 2, 2018.

[15] Y. M. Putra, "Pemetaan Penerapan Standar Akuntansi Keuangan," Profita Komun. Ilm. Akunt. dan Perpajak., vol. 11, no. 2, pp. 201217, 2018.

[16] A. Prajanto and I. Septriana, "Implementasi Penerapan SAK EMKM serta Dampaknya pada Kualitas Pelaporan Keuangan UMKM (Studi Kasus Pada UMKM se-Kota Semarang)," Aset, vol. 20, no. 2, pp. 79-89, 2018.

[17] P. E. S. Devi, N. T. Herawati, and N. L. G. E. Sulindawati, "Pengaruh Tingkat Pendidikan, Pemahaman Akuntansi, Dan Ukuran Usaha Terhadap Kualitas Laporan Keuangan Pada UMKM (Studi Empiris Pada UMKM Di Kecamatan Buleleng)," e-Journal Univ. Pendidik. Ganesha, vol. 8, no. 2, 2017.

[18] N. Salmiah, S. T. Nanda, and I. Adino, "Pemahaman Pelaku UMKM Terhadap SAK EMKM: Survey Pada UMKM Yang Terdaftar di Dinas Koperasi dan UKM Kota Pekanbaru," Akunt. Dewantara, vol. 2, no. 2, pp. 194-204, 2018.

[19] Y. Agustina, S. Setianingsih, and Y. D. Santoso, "Pelatihan Penyusunan Laporan Keuangan Bagi Entitas Mikro, Kecil, dan Menengah Bidang Usaha Dagang pada UMKM Binaan Pusat Inkubasi Bisnis Syariah Majelis Ulama Indonesia," Interv. KOMUNITAS, vol. 1, no. 1, pp. 1-13, 2019.

[20] Ikatan Akuntansi Indonesia, SAK Entitas Mikro Kecil Dan Menengah, 1st ed. Jakarta: Ikatan Akuntansi Indonesia, 2018.

[21] R. A. Rahadi, "Opportunities and Challenges for Micro-Small and Medium Business in Indonesia Facing Asean Economic," $J$. Manaj. DAN KEWIRAUSAHAAN, vol. 18, no. 1, pp. 45-53, 2016.

[22] D. Puryati, "The Influences of Accounting Perception and Knowledge on Implementation of Accounting in Small and Medium Enterprises (SMEs)," South East Asia J. Contemp. Business, Econ. Law, vol. 16, no. 1, pp. 12-21, 2018.

[23] N. M. S. Parwati, J. Nurdin, R. Indriasari, and F. Zahra, "Accounting Practices for Micro Business Financing: a Small Medium Enterprise Case in Palu," in 4th Asian Academic Society International Conference (AASIC) 2016, 2016, pp. 507-513.

[24] N. T. Herawati, I. M. Candiasa, I. K. Yadnyana, and N. Suharsono, "The influence of gender and financial literacy on accounting implementation in small and micro business (SMES)," Int. J. Innov. Creat. Chang., vol. 12, no. 4, pp. 36-50, 2020.

[25] Suparti, Sunaryanto, B. N. Achadiyah, and Dudung Ma'ruf Nuris, "Analysis Of SMEs Readiness in Implementing Financial Accounting," Int. J. Business, Econ. Law, vol. 20, no. 5, pp. 148$155,2019$.

[26] B. D. Anggraeni, "Pengaruh Tingkat Literasi Keuangan Pemilik Usaha Terhadap Pengeloaan Keuangan. Studi Kasus: Umkm Depok," J. Vokasi Indones., vol. 4, no. 1, 2016.

[27] Y. C. Purnama, "Pengaruh Kecerdasan Emosional, Pengalaman, dan Latar Belakang Pendidikan Terhadap Tingkat Pemahaman Akuntansi (Studi Empiris Pada Pelaku UMKM di Kota Bandung)," Universitas Padjadjaran, Bandung, 2019

[28] M. A. Sholeh, Maslichah, and D. Sudaryanti, "Pengaruh Kualitas SDM, Ukuran Usaha dan Lama Usaha Terhadap Pemahaman UMKM Dalam Menyusun Laporan Keuangan Berdasarkan SAK EMKM," E-JRA, vol. 9, no. 7, pp. 44-54, 2020. 